Provided for non-commercial research and education use. Not for reproduction, distribution or commercial use.

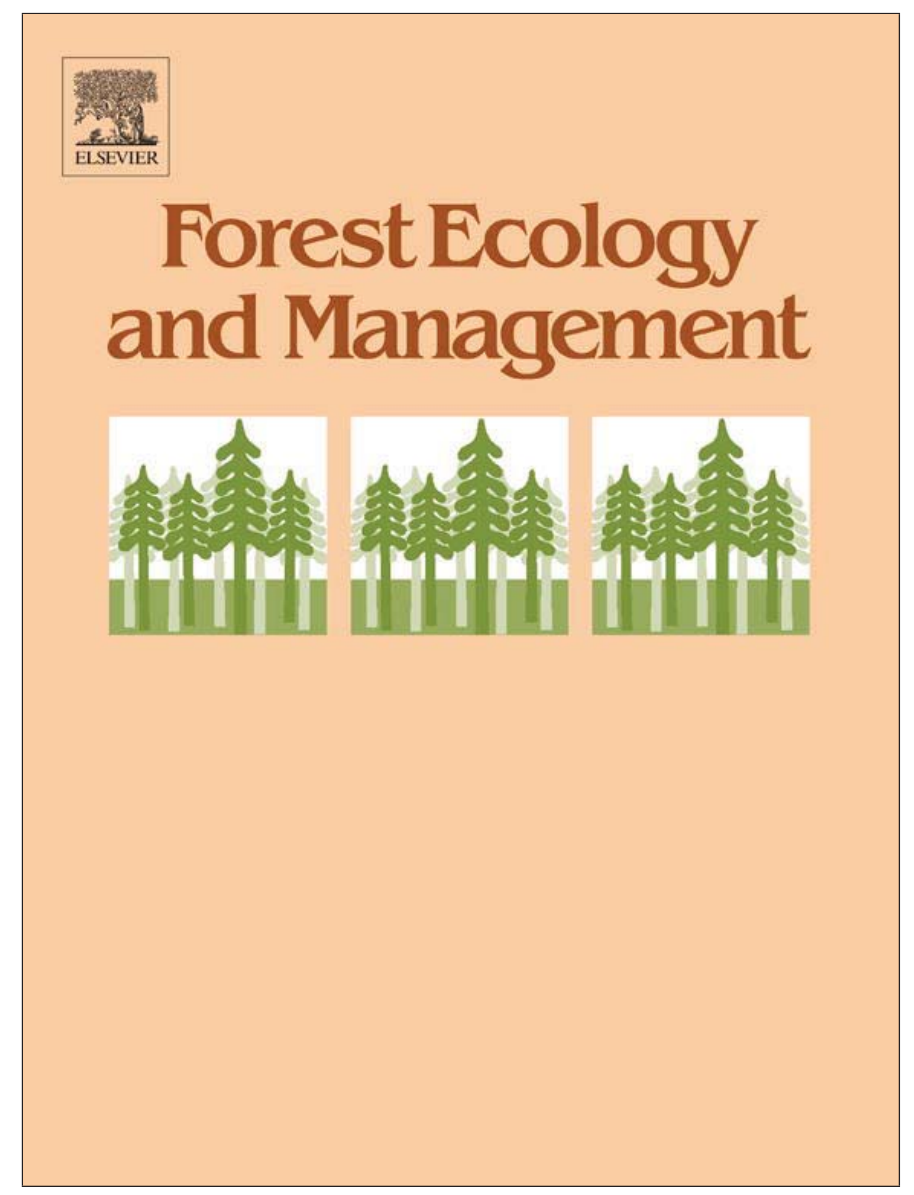

(This is a sample cover image for this issue. The actual cover is not yet available at this time.)

This article appeared in a journal published by Elsevier. The attached copy is furnished to the author for internal non-commercial research and education use, including for instruction at the authors institution and sharing with colleagues.

Other uses, including reproduction and distribution, or selling or licensing copies, or posting to personal, institutional or third party websites are prohibited.

In most cases authors are permitted to post their version of the article (e.g. in Word or Tex form) to their personal website or institutional repository. Authors requiring further information regarding Elsevier's archiving and manuscript policies are encouraged to visit:

http://www.elsevier.com/copyright 


\title{
Climate induced birch mortality in Trans-Baikal lake region, Siberia
}

\author{
V.I. Kharuk $^{\text {a,* }}$, K.J. Ranson ${ }^{\text {b }}$, P.A. Oskorbin ${ }^{\text {a }}$, S.T. Im ${ }^{\text {a }}$, M.L. Dvinskaya ${ }^{\text {a }}$ \\ ${ }^{\text {a } V . N . ~ S u k a c h e v ~ I n s t i t u t e ~ o f ~ F o r e s t ~ a n d ~ S i b e r i a n ~ F e d e r a l ~ U n i v e r s i t y, ~ K r a s n o y a r s k, ~ R u s s i a ~}$ \\ ${ }^{\mathrm{b}}$ NASA's Goddard Space Flight Center, Greenbelt, MD 20771, USA
}

\section{A R T I C L E I N F O}

Article history:

Received 27 July 2012

Received in revised form 10 October 2012

Accepted 12 October 2012

\section{Keywords:}

Climate-induced tree mortality

Drought impact

Forest die-off

Forest-steppe

Betula pendula

\begin{abstract}
A B S T R A C T
The Trans-Baikal (or Zabailkal'e) region includes the forest-steppe ecotones south and east of Lake Baikal in Russia and has experienced drought for several years. The decline and mortality of birch (Betula pendula) stands within the forest-steppe ecotone Trans-Baikal region was studied based on a temporal series of satellite data, ground measurements, and tree ring analysis. During the first decade of the 21st century birch stands decline and mortality were observed on about $5 \%$ of the total area of stands within our $1250 \mathrm{~km}^{2}$ study area. Birch forest decline and mortality occurs mainly at the margins of stands, within the forest-steppe ecotone on slopes with direct insolation. During the first decade of the 21st century summer (June-August) precipitation was about $25 \%$ below normal. Soil water content measurements were lowest within dead stands and highest within healthy stands and intermediate within damaged stands. Drought impact on stands was amplified by an increase in summer air temperatures $\left(+0.9^{\circ} \mathrm{C}\right)$ in comparison with the previous decade. Tree ring data of "surviving" and "dead" tree groups showed a positive correlation with summer/annual precipitation and negative correlation with summer air temperatures. Temperature and precipitation extreme anomalies tend to occur in the region with a period of about 27 years. The observed anomaly was the most severe since the beginning of meteorological observations in the year 1900. Data for the other sites showed a positive climate impact on the growth and expansion of Siberian forests. That is, the same species (B. pendula) showed considerable increase (1.4 times both in height and stem volume) during 20th-21st centuries as temperature increased but precipitation remained at adequate levels.
\end{abstract}

(c) 2012 Elsevier B.V. All rights reserved.

\section{Introduction}

Drought-induced forest decline and die-off during the last decades has been documented on every continent (Allen et al., 2009). Forest mortality caused by elevated temperatures and water stress was reported for Europe, including increased mortality among many tree species in Spain (Peñuelas et al., 2001), France (Breda et al., 2006; Landmann et al., 2006), and increases in mortality of Pinus sylvestris in Switzerland and Italy (Bigler et al., 2006; Dobbertin and Rigling, 2006), and Populus tremuloides mortality across a million hectares was observed in Canada (Hogg et al., 2008) and in the US (Anderegg, 2012). Drought-induced tree mortality was also documented for over a million hectares of Pinus edulis in the south-western part of USA (Swetnam and Betancourt, 1998; Breshears et al., 2005; Raffa et al., 2008; van Mantgem et al., 2009). In Russia, birch stands decline was described for southeast Siberia by Anenkhonov (2008).

Future climate changes are likely to include further increases in drying, frequency and severity of droughts in some forested areas (Christensen et al., 2007; Seager et al., 2007; Sterl et al., 2008; Allen

\footnotetext{
* Corresponding author.

E-mail address: kharuk@ksc.krasn.ru (V.I. Kharuk).
}

et al., 2009). Negative impacts on forests include reduced growth and increases in stress and mortality caused by synergy of air temperature and precipitation change and climate-induced changes in the dynamics of dendrophyl insects and fungi (Lucht et al., 2006; Scholze et al., 2006; Lloyd and Bunn, 2007).

Forested areas are especially sensitive to climate variables within ecotones, the transitions between different vegetation types, where tree growth is limited by temperature and/or precipitation (Holtmeier, 2009). Climate change scenarios predict aridization and risk of conversion of forest-steppe ecotones into steppe or deserts, and northward expansion of steppes (IPCC, 2007).

The goal of this paper is an analysis of climate-induced impacts on birch stands within the forest-steppe ecotone in the TransBaikal area, the transition between boreal forests and Mongolian steppes and deserts (Fig. 1). We hypothesize that air temperatures and precipitation changes during past decades will impact tree vegetation vigor within the Trans-Baikal forest-steppe.

\section{Study areas}

The study area location is shown in Fig. 1. The Trans-Baikal area (also known as Zabailkal'e) is located to the south and east of Lake 


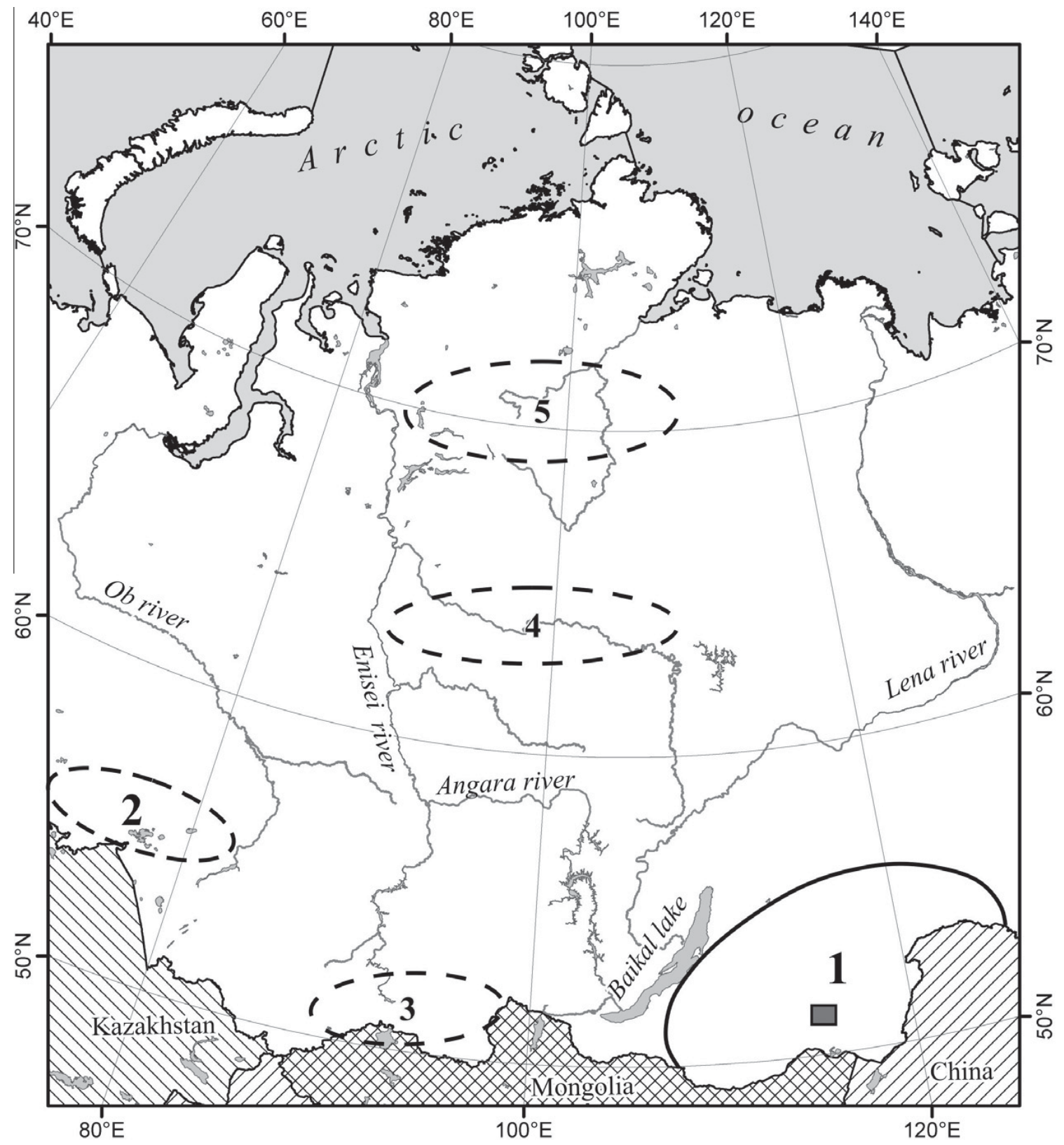

Fig. 1. Trans-Baikal study area location (1). 2-5 - show locations for sites of former studies (2 - Western Siberia forest-steppe ecotone, 3 - alpine ecotone in Altay-Sayan Mountains; 4 - larch - mixwood taiga ecotone; 5 - northern forest-tundra ecotone; Kharuk et al., 2006-2011). Square indicates on-ground area, Landsat and Quickbird scenes location $\left(116^{\circ} \mathrm{E} / 51^{\circ} 25^{\prime} \mathrm{N}\right.$ cent point coordinates).

Baikal in southern Siberia $\left(53^{\circ} \mathrm{N} 117^{\circ} \mathrm{E}\right)$ and is composed of hills and mountains with elevations up to $2500 \mathrm{~m}$.

Forests were presented by a mosaic of birch-dominated stands (Betula pendula) embedded within the southern Siberian steppe, and occupying mainly north facing mountains slopes (up to $1200 \mathrm{~m}$ in elevation). Scots pine (Pinus silvestris) and Siberian larch (Larix sibirica) were presented by rare specimens. Within study area mean density of stands was 1100 trees/ha, mean age was about 40 years old; mean tree heights, dbh, and stem volume were $12 \mathrm{~m}, 13.5 \mathrm{~cm}$, and $90 \mathrm{~m}^{3} / \mathrm{ha}$, respectively. South facing slopes were covered by grass communities. Soils were rocky podzols. Ground water level was at about tens meters.

\subsection{Climate}

The climate is severe continental with harsh cold winters and warm summers. During the last four decades mean annual air temperature and precipitation were $-2.7^{\circ} \mathrm{C}$ and $330 \mathrm{~mm}$. Mean summer (June-August) and winter (December-February) temperature and precipitation were $+16.5^{\circ} \mathrm{C},-24.0^{\circ} \mathrm{C}$, and $232 \mathrm{~mm}$ and $8 \mathrm{~mm}$, respectively. During the last two decades (vs the similar previous period) an increase in mean annual temperature $\left(+1.1{ }^{\circ} \mathrm{C} ; p<0.01\right)$, a decrease in annual $(-37 \mathrm{~mm}$, or $>10 \%)$ and a decrease in summer $(-38 \mathrm{~mm}$, or $>15 \%$; $p<0.05)$ precipitation were observed. 


\section{Materials and methods}

\subsection{Satellite data}

A temporal series of satellite data were compiled from Terra/ MODIS (http://cimss.ssec.wisc.edu/dbs/China2011/Day2/Lectures/ MODIS_MOD13_NDVI_referenc.pdf) and Landsat scenes (https:// wist.echo.nasa.gov; http://edcsns17.cr.usgs.gov). Ancillary data sets included MODIS-based vegetation map with $250 \mathrm{~m}$ resolution (TerraNorte, http://terranorte.iki.rssi.ru), topography data (http:// www.cgiar-csi.org), and a Quickbird scene ( $\sim 2 \mathrm{~m}$ resolution). Terra/MODIS and Landsat data were used to generate temporal row of vegetation indexes (Enhanced Vegetation Index, EVI, and Normalized Vegetation Index, NDVI) analysis within the study area. EVI was defined as:

$E V I=G \cdot\left(\rho_{\text {NIR }}-\rho_{\text {red }}\right) \cdot\left(\rho_{\text {NIR }}+C 1 \cdot \rho_{\text {red }}-C 2 \cdot \rho_{\text {blue }}+L\right)^{-1}$

where $\rho_{\text {NIR }}, \rho_{\text {red }}$ and $\rho_{\text {blue }}$ are atmospherically-corrected surface reflectance in MODIS bands \#1 (620-670 nm), \#2 (841-876 nm) and \#3 (459-479 nm); $L$ is the canopy background adjustment; $C 1$ and $C 2$ are the coefficients of the aerosol correction; $G$ - gain factor (Huete et al., 1999). EVI, as well as NDVI is responsive to canopy structural variations, including leaf area index (LAI), canopy type, plant physiognomy, and canopy architecture (Huete et al., 2002). Analysis revealed that both Vis, EVI and NDVI performed equally well (Wardlow et al., 2010). Technically EVI data are available as a ready MODIS product MOD13Q1 from NASA's site (EOSDIS: http://reverb.echo.nasa.gov). In this study EVI values covered the period from 2000 to 2010.

The MODIS vegetation map and topography data were used to generate a mask of forest stands. Landsat and Quickbird scenes were used for detailed analysis where ground measurements were acquired within the study area (Fig. 6). Both Landsat scenes were taken within the same vegetative period [i.e., 28 July 2000 (Landsat 5) and 24 July 2010 (Landsat 7)]. Since the sensors were different, the Landsat-5 scene was calibrated against Landsat-7. Geometrical correction was performed using "rubber sheeting" (Erdas, 2010). Radiometric corrections were made for bands \#3 (630-690 nm) and \#4 (760-900 nm) based on spectral signatures of ground surfaces with relatively stable spectral characteristics (sands, water bodies, rock outcrops) (Fig. 2). Within the Landsat scenes identification of dead, damaged and healthy stands was based on ground based observations and Quickbird data.

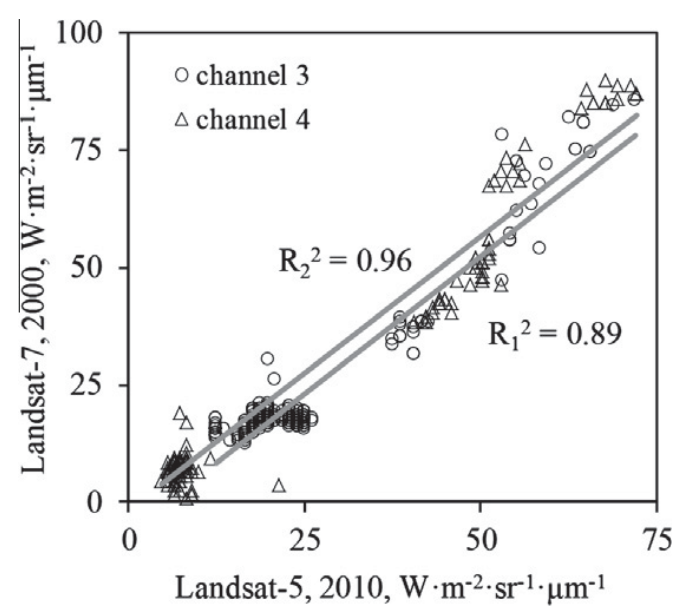

Fig. 2. Landsat-5 against Landsat-7 regression data for channels 3 and 4 . Data were calibrated based on the 335 reference points within area of about 34,0000 ha.
Burned areas were excluded by using a mask which was generated based on the MODIS Burned Area Product (MCD45 MODIS: https://wist.echo.nasa.gov). Wildfires within the study area were observed mainly within the steppe communities. So annual forest stand damage was $<5 \%$ of the total burned area mapped by MODIS. Burns were regenerated with grasses and restored to the pre-fire vegetation index values during the following year (E. Ponomarev, personal communication). Based on this, it was assumed that MODIS spectral signatures for a given year were affected by current year fires only.

\subsection{Ground studies}

Ground data were acquired during first 10 days of July 2011. Forest inventory and soil measurements were made along transects from dead into healthy stands $(N=7$; mean length $=70 \mathrm{~m}$; elevations range from 460 to $870 \mathrm{~m}$ ). Measurements were made within circular $(r=9.8 \mathrm{~m})$ test plots $(N=21)$ along transects. Measured parameters were tree heights, dbh (diameter at breast height) and tree status (healthy, declined or dead) (Forest Inventory Instruction for Russian Forest, 1995).

Soil moisture measurements were based on samples taken at the 25 and $50 \mathrm{~cm}$ depth. Weather conditions in the area prior to and during measurements were dry with no precipitation observed during the sampling periods and only 7-10 $\mathrm{mm}$ a week before recorded at the nearest weather station. Soil samples $(N=131)$ were obtained from 21 soil profiles. Samples were placed into an aluminum box and immediately weighed. Samples were oven dried in the laboratory at $85-90^{\circ} \mathrm{C}$ and weighed again. Percent of soil moisture was calculated based on the weight difference measured preand post-drying.

\subsection{Normalized hydrothermal index}

Stands water supply was estimated based on Normalized Hydrothermal Index (NHI):

$$
\begin{aligned}
& \mathrm{NHI}=\mathrm{p}_{\text {norm }} / \mathrm{t}_{\text {norm }}, \\
& \begin{aligned}
\text { where } p_{\text {norm }} & =\left[\left(p_{i}-p_{\min }\right) /\left(p_{\max }-p_{\min }\right)+1\right], \quad t_{\text {norm }} \\
& =\left[\left(t_{i}-t_{\min }\right) /\left(t_{\max }-t_{\min }\right)+1\right],
\end{aligned}
\end{aligned}
$$

$p_{\text {norm }}$ and $t_{\text {norm }}$ are the normalized precipitation and temperature, correspondingly scaled to range [1,2]; $i$ is the given year; $p_{i}$ is sum of summer monthly precipitation $[\mathrm{mm}], t_{i}$ is mean summer (June-August) temperature $[\mathrm{K}], p_{\min }, p_{\max }, t_{\min }$, and $t_{\max }$ are minimum and maximum summer precipitations and temperatures, correspondingly during 1901-2009 years. Normalization within range $[1,2]$ allowed to equalize an input of precipitation and temperature into index values.

NHI index was similar to Selyaninov hydrothermal index (Meshcherskaya and Blazhevich, 1997), which was defined as:

$\mathrm{HI}=\mathrm{R} / 0.1 \Sigma t$,

where $R$ is the sum of precipitation during a vegetation season when $t>+10^{\circ} \mathrm{C}, t$ is the sum of the temperatures for the same period. Kelvin degrees $[\mathrm{K}]$ were used to avoid negative values when using Celsius scale. Normalized Hydrothermal Index Anomaly (NHIA) were calculated based on:

$\mathrm{NHIA}=\mathrm{NHI}_{i}-\mathrm{NHI}_{\text {mean }}$,

where $\mathrm{NHI}_{i}$ is $\mathrm{NHI}$ for the given year $i$ and $\mathrm{NHI}_{\text {mean }}$ is mean $\mathrm{NHI}$ for the given period. 

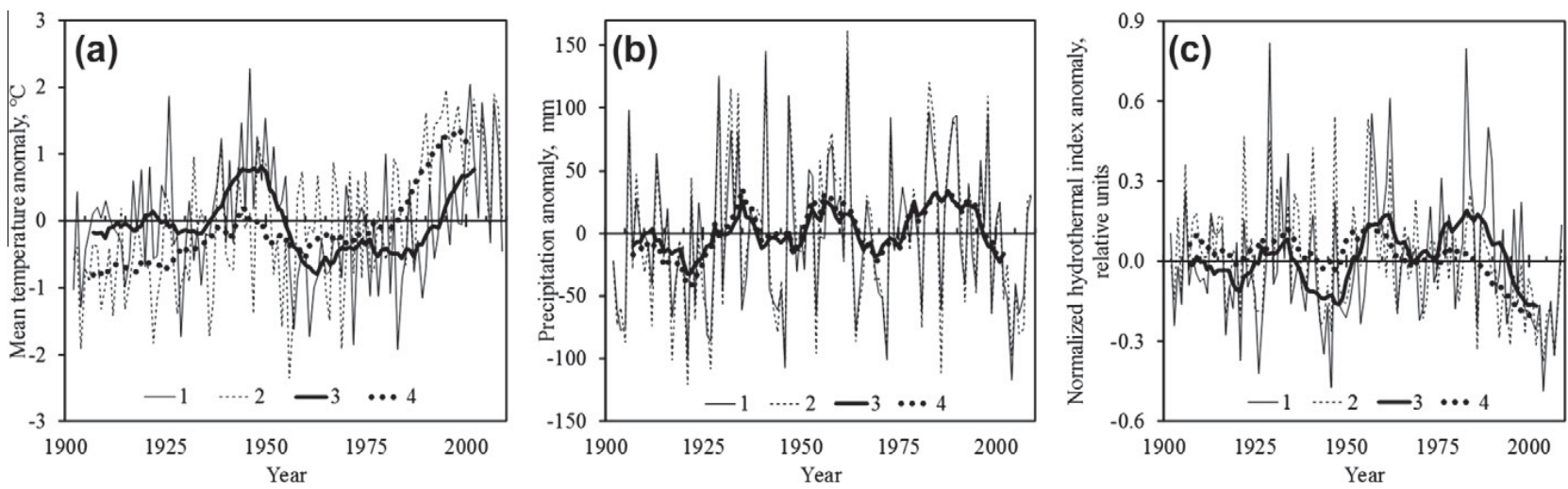

Fig. 3. Air temperature (a), precipitation (b) and hydrothermal index (c) anomaly in the Trans-Baikal zone. 1 - annual, 2 - summer data; 3 and 4 - summer and annual data filtered by 13 -years moving window.

\subsection{Climate data}

Climate data were obtained from KNMI Climate Explorer (http://climexp.knmi.nl). CRU TS3.1 provides climate data averaged for a cell size $0.5^{\circ} \times 0.5^{\circ}(\sim 70 \times 70 \mathrm{~km}$; Mitchell and Jones, 2005).

\subsection{Dendrochronology analysis}

On each test plot 3-5 trees were cut at the root neck level and disks were obtained for dendrochronology analysis. The surface of each sampled disk was sanded or scraped to enhance visibility of the tree rings. The widths of tree rings were measured with $0.01 \mathrm{~mm}$ precision using a linear table instrument (LINTAB-III). Samples were put into two groups: "dead" (22 specimens) and "survived" (11 specimens). The mean tree ages of "dead" and "survived" groups were 54 and 56 years, respectively. The TSAP and COFECHA computer programs were used in tree ring analysis (Holmes, 1983; Rinn, 1996).

\section{Results}

\subsection{Climate}

Analysis of available climate data (since 1900) showed positive trends during 1960-2009 for annual, summer (June-August), and winter air temperatures $(p<0.05)$, and for summer temperatures during 1928-1947 ( $p<0.01$; Fig. 3). A negative summer temperature trend was observed during 1947-1960. Annual and summer precipitations showed positive trends in 1965-1990 $(p<0.01)$, and negative trends during 1957-1970 (annual and summer precipitation; $p<0.05$ ) and 1988-2006 years (summer precipitations; $p<0.01$ ). The trend of summer hydrothermal index was negative during 1930-1946, 1957-1970 and in 1983-2009 years $(p<0.01)$, and positive during 1970-1983 ( $p<0.05)$. Fourier-analysis revealed a $\sim 27$ years cycle in summer air temperature and precipitation. The processed data (filtered by 13 -years filter, i.e., $\sim 1 / 2$ of the 27 -year detected cycle) are presented on Fig. 3 .

\subsection{Trends of satellite data}

Satellite-derived vegetation indexes of birch stands showed a decrease during the $2000-2010$ time period. For about $5 \%$ of the total area of stand's (or about $1250 \mathrm{~km}^{2}$ ) enhanced vegetation index (EVI) decrease was significant at $p<0.05$ (Fig. 4). Landsat-derived

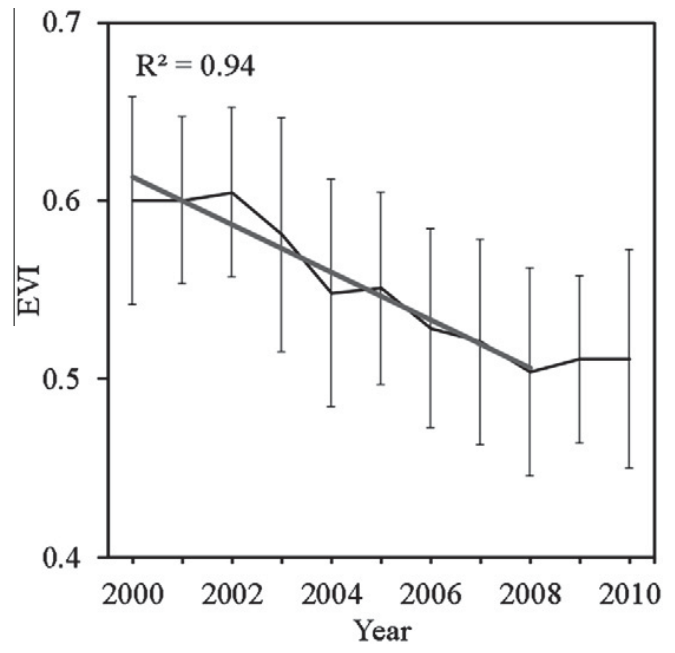

Fig. 4. MODIS-derived EVI values for the birch stands. Trend were significant at $p<0.05$. Observed effect of EVI decrease is about two times higher (13\% per decade vs max. $7 \%$ per decade) than MODIS sensor degradation.

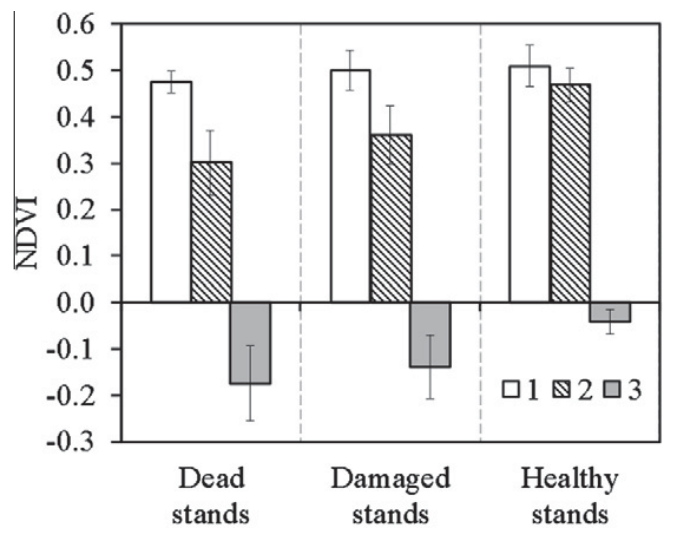

Fig. 5. Birch stand's NDVI values for the years 2000 (1) and 2010 (2); 3 - delta NDVI $\left(\mathrm{NDVI}_{2010}-\mathrm{NDVI}_{2000}\right)$. Data are significant for dead and damaged stands $(p<0.01)$. Note: all stands used for the study were alive in the year 2000 .

data showed NDVI values decreased with the maximum rate of decrease occurring for dead stands (Fig. 5). 


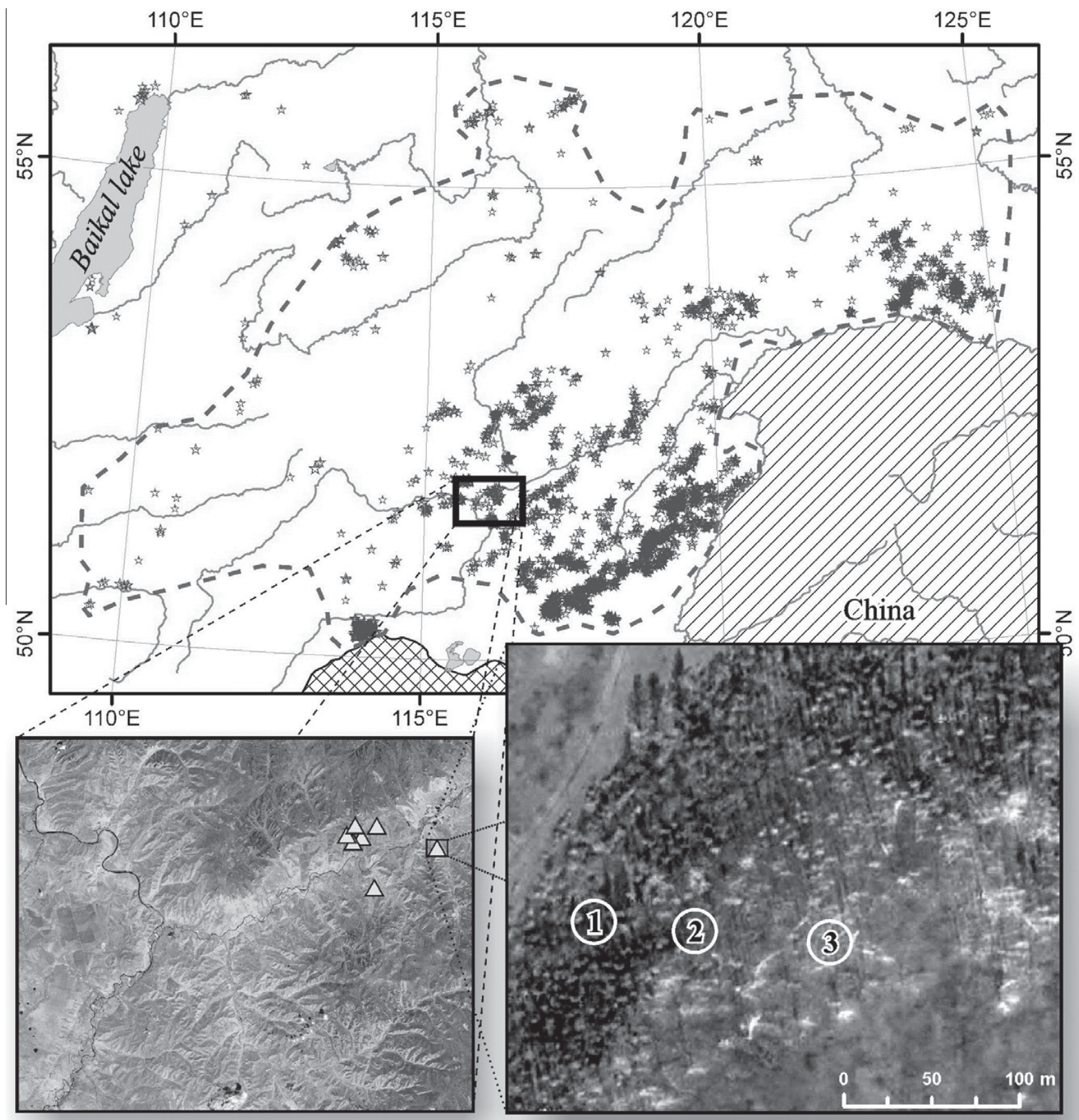

Fig. 6. MODIS-derived sketch-map classification: location of the drought damaged and dead stands shown by symbols. Total affected area $\left(\sim 40,0000 \mathrm{~km}{ }^{2}\right)$ bounded by the dotted line. Insets. Left: Landsat scene fragment which was used for NDVI-based stands vigor classification (Fig. 5); triangles indicated transect location. Right: Quickbird scene showed healthy (1), damaged (2) and dead (3) stands location.

\subsection{Ground data}

Ground based measurements showed that birch forest decline and mortality was mainly observed at the margins of stands within the forest-steppe contact zone. Drought damaged and dead stands occurred in strips of forests that were about $22 \pm 5 \mathrm{~m}$ and $40 \pm 11 \mathrm{~m}$ wide, respectively (Fig. 6). Damaged stands were located on the sunlit slopes (i.e., south, southwest and southeast facing slopes). An example of the observed damage is shown in the inset photograph of Fig. 7). Soil water content was found be minimal within dead stands, maximum within healthy stands and intermediate within declining stands (Fig. 7). There were no signs of insect or fungi attack on the trees.

Birch stand mortality promotes the rapid establishment of a grass cover due to a decrease in competition for water, nutrients and light. Height of grasses established within damaged forest area was about 2-3 times taller than within drought unaffected stands (30-40 cm vs $10-15 \mathrm{~cm}$ ).

Dendrochronology data for two tree groups ("dead" and "surviving") showed that incremental growth values were similar up 


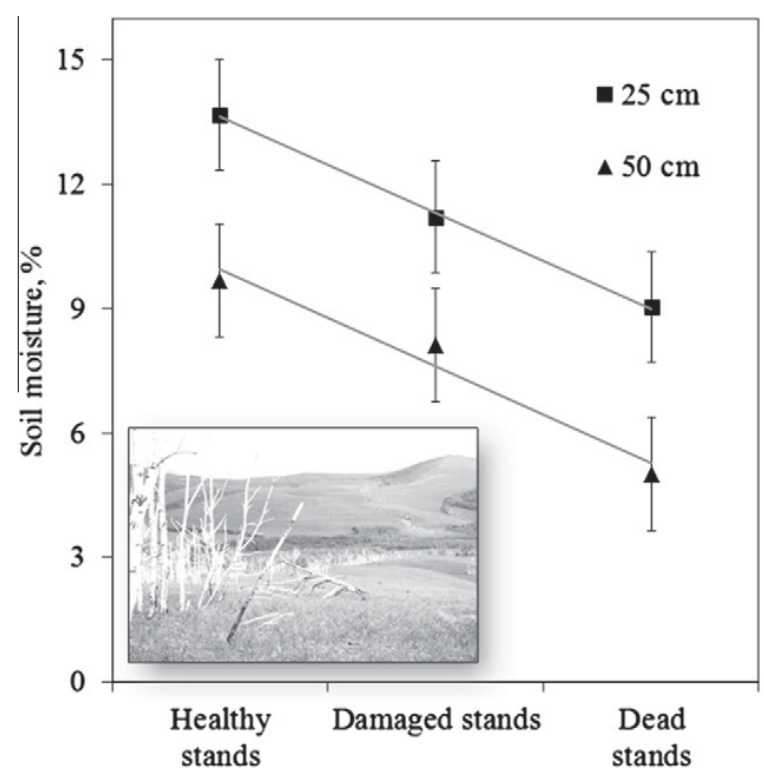

Fig. 7. Soil moisture content at 25 and $50 \mathrm{~cm}$ depth for the healthy, damaged and dead stands. Inset: Birch dieback pattern shown occurs in strips at the margins of forest stands.

to the beginning of the 1970s. Later the stands that eventually died (dead group) showed lower incremental growth values (Fig. 8). The majority of tree dieback occurred during 2003-2005 (Fig. 8).

Tree ring widths of "surviving" and "dead" groups were correlated with climate variables. For "survivors" this relation was described by:

$T_{w}=-0.30 t_{m a}+0.63 P_{m a} ; \quad R^{2}=0.70$,

where $T_{w}$ is average tree ring width, $t_{m a}$ and $P_{m a}$ are May-August temperature and precipitation, respectively. The equation is significant at $p<0.05$. Coefficients for $t_{m a}$ and $P_{m a}$ are significant at $p<0.01$ and at $p<0.001$, respectively.For the "dead" group the equation is as follows:
$T_{w}=-0.42 t_{m a}+0.44 P_{m a} ; R^{2}=0.55$; equation significant at $p<0.03$. The coefficients for $t_{m a}$ and $P_{m a}$ are significant at $p<0.01$ and at $p<0.005$, respectively.

\section{Discussion}

The Trans-Baikal forest-steppe ecotone is an area of low precipitation (about, $330 \mathrm{~mm}$ total). Summer precipitation decreased (about $\sim 25 \%$ ) during the first decade of the 21st century (vs similar previous period; $p<0.01$; Fig. 3B). This precipitation decrease coincided with an observed decrease in vegetation indices (EVI, NDVI) for an area of about $1250 \mathrm{~km}^{2}$ (i.e., area of birch stands where significant decrease of EVI was recorded), or $5 \%$ of the total area of birch stands; Figs. 4, 5 and 6); both events were correlated $(r=0.76)$. It should be noted that the Terra/MODIS sensor showed degradation over the time period of this investigation, i.e. decreasing of the recorded radiometric response at the rate of about from $1-2 \%$ to $4-7 \%$ per decade, depending on the spectral channel (Wang et al., 2012). This sensitivity decrease may cause a temporal decrease in the EVI values with maximum estimated effect of about $7 \%$ per decade. Meanwhile, the observed decrease of EVI was about twice higher (13\% per decade), i.e., the effect of birch stands EVI decrease was not an artifact.

The birch stands studied were strongly sensitive to summer precipitation anomalies because of extremely low winter precipitation $(<10 \mathrm{~mm})$, low fall $(\sim 50 \mathrm{~mm})$ and spring $(\sim 40 \mathrm{~mm})$ precipitation. In addition, soils (rocky podzols) within the study area have a low water holding capacity, with water table location far below the birch root zone (i.e., within $10-100 \mathrm{~m}$, whereas depth of birch roots (at Age $=50$ years) is about $4.0 \mathrm{~m}$; Vorobjeva, 1959). The exception is a minor portion of the region underlain by permafrost, where available moisture was higher due to thawing permafrost, as well as in areas of perched water tables due to permafrost. Soil water content within dead stands was about 30$50 \%$ lower than within alive stands (Fig. 7). Stands mortality occurs in a strip pattern located within the birch-steppe boundary on the southern and south-facing slopes with relatively drier and warmer conditions. A similar observation was described for aspen stands mortality in the western US (Huang and Anderegg, 2012). Drought

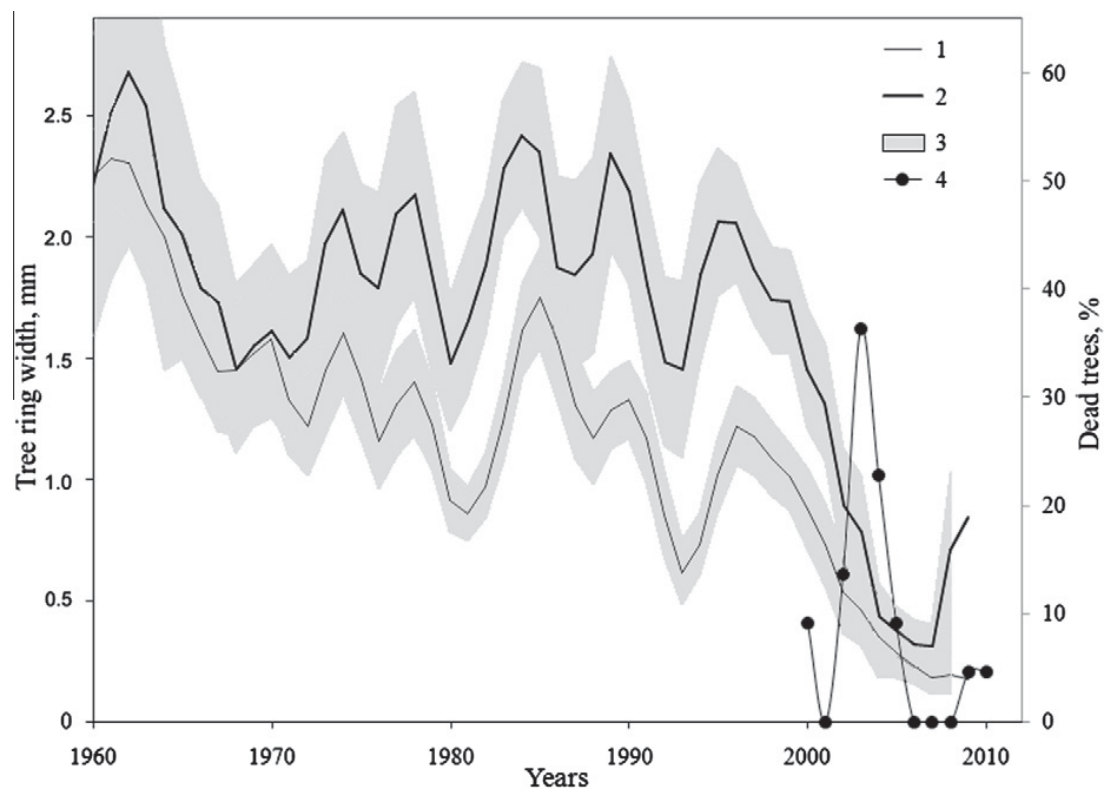

Fig. 8. Dynamics of tree ring width for the "dead" (1) and "survived" (2) stands; 3 - confidence level $(p<0.05), 4-$ percentage of sampled dead trees $(N=22)$ dying in the given year. Data were filtered with a 3-years moving window. 
impact on stands was amplified by an increase in summer air temperature $\left(+0.9{ }^{\circ} \mathrm{C}\right.$ in comparison with the previous decade; $p<0.02$; Fig. 2A). Recent advances in the understanding of tree mortality mechanisms suggest that forests could be particularly sensitive to increases in temperature in addition to drought alone (Allen et al., 2009). The hydrothermal index, which includes both temperature and precipitation data, showed the greatest decreases have occurred since the year 2000 (Fig. 3c).

All drought-killed trees died in the period of 2000-2010 with maximum mortality occurring during 2002-2004 years, i.e., within the maximum period of drought (Fig. $3 \mathrm{~b}$ and c). Notably, the initial tree ring increment for the "dead" and "survived" groups was similar. A deviation occurred between groups at the end of 1970 s through the beginning of the 1980 s, i.e., during the previous drought cycle that peaked in 1972 (Fig. 8). With precipitation and hydrology index increases during the late 1980s tree ring growth also increased. With ending of the current drought (2009-2010) "survivors" again showed a growth increase (Fig. 2b and $\mathrm{c}$ and Fig. 8). The last event was accompanied by leveling off of EVI following the decline from 2002-2008 (Fig. 4). Tree-ring studies of aspen growth under drought also document large decreases in basal trunk growth during drought years (Hogg et al., 2005).

Along with temperature and precipitation, wildfires may have a potential input to the forest decline and dieback. However, wildfires occurred mainly within the steppe grass communities. Ground studies showed that burns were infrequent and wildfires were not the primary cause of birch mortality. Similar observations were reported by Anenkhonov (2008).

The 27 year cycles in precipitation and air temperature suggest that similar birch die-off occurred in the past and may occur again in the future. The next drought can be expected around the year 2030 and expected to be more severe since even conservative climate scenarios predict an increase of extreme hot temperatures (IPCC, 2007). This is supported by the data obtained. Based on the results temperature and hydrology index anomalies associated with the birch decline were extreme during period of meteorological observations (Fig. 2a and c). Thus, increasing birch stand damage may be expected in the future. In the light of this fact larch should be considered a preferable species for re-forestation since larch exceeds birch in drought resistance. Moreover, according to local historical data larch was in the past a dominant species in the Trans-Baikal area but was selectively removed by harvesting.

Finally, the described birch die-off phenomenon in the TransBaikal region is a part of the broader climate-induced changes within Siberian forests. Published data showed a positive climate change impact on the growth and expansion of Siberian forests. Thus, similar species (B. pendula) in West Siberia forest-steppe ecotone under higher temperatures, but sufficient precipitation, showed considerable increase (1.4 times both in height and stem volume) during 20th-21st centuries (e.g., site 2 in Fig. 1). Climate-induced forest density increases and upslope tree migration were reported for an alpine forest-tundra ecotone in Altai-Sayan Mountains (site 3 in Fig. 1, Kharuk et al., 2009, 2010, 2011). Tree migration into tundra and stand densification was observed within northern forest boundary in Siberia (Fig. 1, site 4; Kharuk et al., 2006) and in the Polar Ural Mountains (Devi et al., 2008). Along with this, climate-driven migration of Siberian pine and spruce into traditional larch habitat has been reported (Fig. 1, site 5; Kharuk et al., 2007).

\section{Acknowledgments}

This research was supported by the SB RAS Program No. 30.3.33, and NASA Science Mission Directorate, Terrestrial Ecology Pro- gram. The authors thank Dr. Joanne Howl for editing the manuscript.

\section{References}

Allen, C.D., Macalady, A.K., Chenchouni, H., Bachelet, D., McDowell, N., Vennetier, M., Kitzberger, T., Rigling, A., Breshears, D.D., Hogg, E.H., Gonzalez, P., Fensham, R., Zhang, Z., Castro, J., Demidova, N., Lim, J.H., Allard, G., Running, S.W., Semerci, A., Cobb, N., 2009. A global overview of drought and heat-induced tree mortality reveals emerging climate change risks for forests. Forest Ecology and Management. http://dx.doi.org/10.1016/j.foreco.2009.09.001.

Anderegg, W.R.L., 2012. Complex aspen forest carbon and root dynamics during drought. Climate Change. http://dx.doi.org/10.1007/s10584-012-0421-9.

Anenkhonov O.A., 2008. The current state of forest components within the foreststeppe zone of Transbaikalia in connection with the climate change. Materials of the International Symposium "Climate Change in Central Asia: SocioEconomic and Environmental Impacts". October 24, 2008, Chita, Russia, pp. 149-153.

Bigler, C., Braker, O.U., Bugmann, H., Dobbertin, M., Rigling, A., 2006. Drought as an inciting mortality factor in Scots pine stands of the Valais, Switzerland. Ecosystems 9, 330-343.

Breda, N., Huc, R., Granier, A., Dreyer, E., 2006. Temperate forest trees and stands under severe drought: a review of ecophysiological responses, adaptation processes and long-term consequences. Annals of Forest Science 63, 625-644.

Breshears, D.D., Cobb, N.S., Rich, P.M., Price, K.P., Allen, C.D., Balice, R.G., Romme W.H., Kastens, J.H., Floyd, M.L., Belnap, J., Anderson, J.J., Myers, O.B., Meyer, C.W. 2005. Regional vegetation die-off in response to global-change-type drought. Proceedings of the National Academy of Sciences of the United States of America 102 (42), 15144-15148.

CGIAR Consortium for Spatial Information. <http://www.cgiar-csi.org>.

Christensen, J.H., Hewitson, B., Busuioc, A., Chen, A., Gao, X., Held, I., Jones, R., Kolli, R.K., Kwon, W.-T., Laprise, R., Magaña Rueda, V., Mearns, L., Menerndez, C.G., Raisanen, J., Rinke, A., Sarr, A., Whetton, P., 2007. Regional climate projections. In: Solomon, S. et al. (Eds.), Climate Change: The Physical Science Basis. Contributions of Working Group I to the Fourth Assessment Report of the Intergovernmental Panel on Climate Change. Cambridge University Press, Cambridge, United Kingdom/New York, NY.

Climate Explorer. <http://climexp.knmi.nl>.

Devi, N., Hagedorn, F., Moiseev, P., Bugmann, H., Shiyatov, S., Mazepa, V., Rigling, A. 2008. Expanding forests and changing growth forms of Siberian larch at the Polar Urals tree line during the 20th century. Global Change Biology 14, 15811591.

Dobbertin, M., Rigling, A., 2006. Pine mistletoe (Viscum album ssp. austriacum) contributes to Scots pine (Pinus sylvestris) mortality in the Rhone valley of Switzerland. Forest Pathology 36, 309-322.

EOSDIS. <http://reverb.echo.nasa.gov>.

ERDAS, Inc., 2010. Erdas Imagine FieldGuide, Erdas, Inc., USA, 842pp. <http:// www.erdas.com/Resources/ERDASFieldGuide.aspx>.

Forest Inventory Instruction for Russian Forest Part 1 1995. M.: All-Russian Scientific Research Center of the Forest Resource, 174p.

Hogg, E.H., Brandt, J.P., Kochtubajda, B., 2005. Factors affecting interannual variation in growth of western Canadian aspen forests during 1951-2000. Canadian Journal of Forest Research 35, 610-622.

Hogg, E.H., Brandt, J.P., Michaellian, M., 2008. Impacts of a regional drought on the productivity, dieback, and biomass of western Canadian aspen forests. Canadian Journal of Forest Research - Revue Canadienne De Recherche Forestiere 38 1373-1384.

Holmes, R.L., 1983. Computer-assisted quality control in tree-ring dating and measurement. Tree-ring Bulletin 44, 69-75.

Holtmeier, F.-K., 2009. Mountain Timberlines: Ecology, Patchiness, and Dynamics. Kluwer Academic Publishers, Netherlands, 437pp.

Huang, C.-Y., Anderegg, W.R.L., 2012. Large drought-induced aboveground live biomass losses in southern Rocky Mountain aspen forests. Global Change Biology 18, 1016-1027. http://dx.doi.org/10.1111/j.1365-2486.2011.02592.x.

Huete A., Justice C., and van Leeuwen W., 1999. MODIS vegetation index (MOD 13) algorithm theoretical basis document. 129pp.

Huete, A., Didan, K., Miura, T., Rodriguez, E.P., Gao, X., Ferreira, L.G., 2002. Overview of the radiometric and biophysical performance of the MODIS vegetation indices. Remote Sensing of Environment 83, 195-213.

IPCC, 2007. Climate Change 2007: Synthesis Report. Valencia, Spain.

Kharuk, V., Ranson, K., Dvinskaya, M., 2007. Evidence of evergreen conifer invasion into larch dominated forests during recent decades in central Siberia. Eurasian Journal of Forest Research 10 (2), 163-171.

Kharuk, V.I., Ranson, K.J., Im, S.T., Naurzbaev, M.M., 2006. Forest-tundra larch forests and climatic tends. Russian Journal of Ecology 37 (5), 291-298.

Kharuk, V.I., Ranson, K.J., Im, S.T., Dvinskaya, M.L., 2009. Response of Pinus sibirica and Larix sibirica to climate change in southern Siberian alpine forest-tundra ecotone. Scandinavian Journal of Forest Research 24 (2), 130-139.

Kharuk, V.I., Ranson, K.J., Im, S.T., Vdovin, A.S., 2010. Spatial distribution and temporal dynamics of high elevation forest stands in southern Siberia. Global Ecology and Biogeography Journal 19, 822-830.

Kharuk, V.I., Dvinskaya, M.L., Im, S.T., Ranson, K.J., 2011. The potential impact of CO2 and air temperature increases on krummholz's transformation into arborescent form in the southern Siberian Mountains. Arctic, Antarctic and Alpine Research 43 (4), 593-600. 
Landmann, G., Dreyer, E. (Eds.), 2006. Impacts of drought and heat on forest synthesis of available knowledge, with emphasis on the 2003 event in Europe. Annals of Forest Science 3 (6), 567-652.

Lloyd, A.H., Bunn, A.G., 2007. Responses of the circumpolar boreal forest to 20th century climate variability. Environmental Research Letters 2, 045013. http:// dx.doi.org/10:1088/1748-9326/2/4/045013.

Lucht, W., Schaphoff, S., Erbrecht, T., Heyder, U., Cramer, W., 2006. Terrestrial vegetation redistribution and carbon balance under climate change. Carbon Balance and Management 1, 6. http://dx.doi.org/10.1186/ 1750-0680-1-6.

Meshcherskaya, A.V., Blazhevich, V.G., 1997. The drought and excessive moisture indices in a historical perspective in the principal grain-producing regions of the former Soviet Union. Journal of Climate 10, 2670-2682

Mitchell, T.D., Jones, P.D., 2005. An improved method of constructing a database of monthly climate observations and associated high resolution grids. International journal of climatology 25 (6), 693-712.

NASA Warehouse Inventory Search Tool. <https://wist.echo.nasa.gov>.

Peñuelas, J., Lloret, F., Montoya, R., 2001. Severe drought effects on Mediterranean woody flora in Spain. Forest Science 47, 214-218.

Raffa, K.F., Aukema, B.H., Bentz, B.J., Carroll, A.L., Hicke, J.A., Turner, M.G., Romme, W.H., 2008. Cross-scale drivers of natural disturbances prone to anthropogenic amplification: the dynamics of bark beetle eruptions. Bioscience 58, 501-517.

Rinn F. Tsap V 3.6, 1996. Reference manual: computer program for tree-ring analysis and presentation. Bierhelder weg 20, D-69126, Heidelberg, Germany, 263p.

Scholze, M., Knorr, W., Arnell, N.W., Prentice, I., 2006. A climate-change risk analysis for world ecosystems. Proceedings of the National Academy of Sciences of the United States of America 103, 13116-13120.
Seager, R., Ting, M., Held, I., Kushnir, Y., Lu, J., Vecchi, G., Huang, H.-P., Harnik, N., Leetmaa, A., Lau, N.-C., Li, C., Velez, J., Naik, N., 2007. Model projections of an imminent transition to a more arid climate in southwestern North America. Science 316, 1181-1184

Sterl, A., Severijns, C., Dijkstra, H., Hazeleger, W., van Oldenborgh, G.J., van den Broeke, M., Burgers, G., van den Hurk, B., van Leeuwen, P.J., van Velthoven, P., 2008. When can we expect extremely high surface temperatures? Geophysical Research Letters 35, L14703. http://dx.doi.org/10.1029/2008GL034071.

Swetnam, T.W., Betancourt, J.L., 1998. Mesoscale disturbance and ecological response to decadal climatic variability in the American southwest. Journal of Climate $11,3128-3147$.

TerraNorte. <http://terranorte.iki.rssi.ru>.

USGS Earth Explorer. <http://www.edcsns17.cr.usgs.gov>

Van Mantgem, P.J., Stephenson, N.L., Byrne, J.C., Daniels, L.D., Franklin, J.F., Fuler, P.Z., Harmon, M.E., Larson, A.J., Smith, J.M., Taylor, A.H., Veblen, T.T., 2009. Widespread increase of tree mortality rates in the western United States. Science 323, 521-524.

Vorobjeva, T.I., 1959. Some date to the forming of the root system of Betula verrucosa, Betula pubescens, Betula tortuosa and Betula nana. Bulletin of Moscow Society of Naturalists, Department of Biology 64 (3), 63-73.

Wang, D., Morton, D., Masek, J., Wu, A., Nagol, J., Xiong, X., Levy, R., Vermote, E., Wolfe, R., 2012. Impact of sensor degradation on the MODIS NDVI time series. Remote Sensing of Environment 119 (2012), 55-61. http://dx.doi.org/10.1016/ j.rse.2011.12.001.

Wardlow, B.D., Stephen, L., Egbert, S.L., 2010. A comparison of MODIS 250-m EVI and NDVI data for crop mapping: a case study for southwest Kansas. International Journal of Remote Sensing 31 (3), 805-830. http://dx.doi.org/ $10.1080 / 01431160902897858$. 